\title{
EMPIRICAL STUDY ON ALTERNATIVES FOR SAVING AND INVESTING IN THE POST- PANDEMIC PERIOD. CASE STUDY: ROMANIA
}

\author{
Alexandru-Mihai BUGHEANU \\ Bucharest University of Economic Studies, Romania \\ mihai.bugheanu@man.ase.ro \\ Ruxandra DINULESCU \\ Bucharest University of Economic Studies, Romania \\ ruxandra.dinulescu@man.ase.ro \\ Florin PUCHEANU \\ Bucharest University of Economic Studies, Romania \\ florin pucheanu@yahoo.com
}

\begin{abstract}
This paper develops investigations in the field of saving and investing techniques related to the impact of the COVID-19 pandemic on the Romanian trading market. The study focuses particularly on the alternatives for accumulation of money capital which can lead to a positive long-term return.

The research aims to investigate the available current services and opportunities in the Romanian investment market and their returns after the pandemic. Towards this objective, the study presents the past returns for several products and the users' potential risks. Furthermore, an investigation is conducted based on the latest statistics whereas different variants of portfolios are presented. Unlike most of the previous studies, this analysis has a double approach: evaluating viable alternatives depending on several characteristics and simultaneously developing a long-term potential strategy that could be used to ensure the financial future of an individual in the period of the outbreak of the COVID-19 pandemic.

This contribution provides an initial analysis of the saving and investing market of Romania before and after the pandemic.
\end{abstract}

Keywords: covid-19, saving, investing, retirement, mutual funds.

DOI: https://doi.org/10.24818/beman/2021.S.I.2-03

\section{INTRODUCTION}

In the current Romanian economic environment, after the COVID-19 pandemic and still characterized by political instability, it is imperative that any individual has an alternative for the pension system. The 
increasing interest in ensuring financial independence has heightened the necessity for identifying and evaluating new services and products in the economic field. The topic is highly relevant because it could directly influence the life quality of an individual.

The aim for the current paper is to assess various services, products, and their returns after the pandemic period, to determine a potential saving or investing strategy for a person living in a former socialist state which has just recovered from the worldwide pandemic.

The novelty of this paper can be summed up as follows:

- Developing a general saving and investing long-term strategy by actively analyzing the products currently available in the Romanian market for the financial year 2020;

- Presenting three types of investor portfolio selection depending on the appetite for risk.

Of particular interest in the case of Romania is the fact that only a small percentage of the population has a real interest in this field of regular and recurrent savings. In particular, a well-known cause of the low number of investors is the lack of financial education and Romania is below the world average in this topic. First, we need to address from the beginning the fact that in the financial environment a clear and sharp distinction is made between saving and investing.

To put it differently, the aim of saving is to create reserves of money that are kept in conditions of risk as low as possible, or even non-existent. Through the process of saving individuals practically accumulates money capital which is preserved in maximum safety to be used later, or to make some medium- and longterm personal goals (acquisition of goods: house, cars, a high-performance computer, paying tuition fees, financing a vacation or a trip etc.). Secondly, another objective of saving is the fact that it allows the existence of an emergency fund to deal with unforeseen events. In this case the return will be low, in the range of $[0,5]$ percent annually. Nevertheless, it is important, that the yield should be above the inflation rate.

As an illustration, financial instruments or products that meet these requirements include bank deposits, government securities (treasury certificates for the population) and to some extent even municipal bonds. The performance generated from savings in these financial instruments is generally represented by an interest rate (generally fixed but can also be variable).

On the contrary, the process of investing involves taking various risks, the goal being to make a profit as high as possible. Comparatively, in the case of an investment, the issue is no longer to minimize the risk, but to maximize the profit that can be obtained in acceptable risk conditions. With this in mind, this category includes most types of investments: bonds with lower risk issued by private companies, as well as high risk products such as shares listed on the stock exchange or even very high risk: futures and options. 
Given these points, the two processes presented, saving and investing, are fundamentally different financial instruments. First, the distinction refers to:

1. The main purpose of the individual: accumulation of capital in the case of savings or obtaining a profit when considering investments.

2. The risk involved: close to zero when discussing about savings. On the other hand, significantly higher risks in terms of investments.

3. The possible return or performance, which is represented graphically in Figure 1.

In general, the most suitable tools for saving money are those with high liquidity and low risk. Of course, in these conditions the yield obtained will be relatively low. Correspondingly, is important that the return should be above the inflation rate.

\section{LITERATURE REVIEW}

The main interest regarding a normal growth performance in central and eastern European countries is to present the investment needs and the usefulness of its financing. For example, Collins and Rodrik (1991) illustrate various approaches from different studies that try to analyze the quantity of the needed investment as well as the consequent financing requirements for Eastern Europe.

Moreover, as researchers assume, financial represents money and money will always be a continuous emotional baggage, with or without pandemic. This is partially true since individuals' attitudes towards money is an emotional one.

When talking about a positive saving-investment correlation, on a short term, this may occur, even if the capital is mobile across national and international borders, because of prevalence in technological or productivity shocks (Rasin, 1993; Glick, 1995; Eiriksson, 2011), country-size (Harberger, 1980; Murphy, 1984; Baxter, 1993; Bahmani, 2005), endogenous fiscal policy (Levy, 1995), non-traded goods (Dooley et al., 1987), international trading costs (Obstfeld, 2000), financial frictions (Bai, 2010), long-run solvency constraint (Coakley et al., 1996), common deflator (Chu, 2012) and long-run risk component in the shock process (Chang, 2014). 


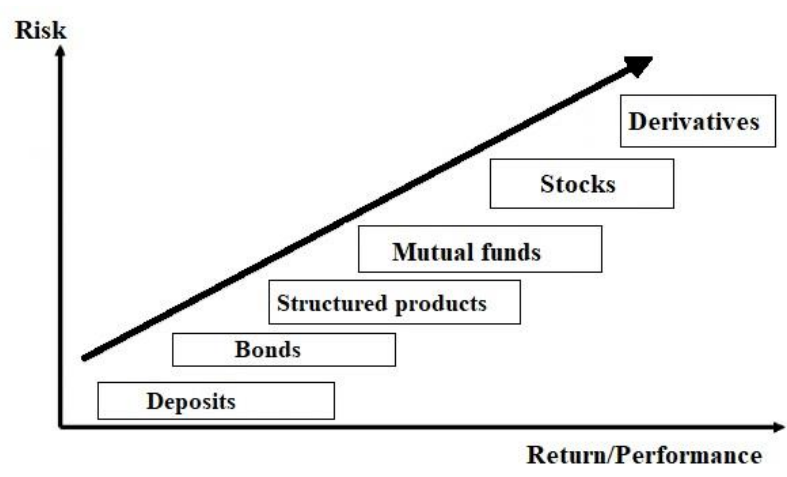

FIGURE 1. RISK/RETURN TRADEOFF

Source: Authors' representation

As Wachtel (2003) states, the stock market will always present a significative interest, because the evolution of the share prices, for the listed companies, will be available for all economic participants. Also, Caporale et al. (2004) imply that more and more efficient allocation of the capital is attained through the liberalization of financial markets, leaving the market to allocate capital. Thus, to achieve the entire efficiency when allocating the capital, it is necessary to maintain a constant level of development of stock markets.

Furthermore, based on Keynes (1936), the individual must take into consideration eight saving reasons, among the most important being "precaution" (ensuring a reserve for unexpected events), "foresight" (guarantee for possible events), and "calculate" (raising financial resources for earning various interests). These are the main three factors that should be considered by any individual who wants to invest on a short-term or long-term plan.

Other reasons why individuals should invest are "retirement", "holidays" and "rainy day" (Harris et al. 2002).

\section{COMPARATIVE ANALYSIS BETWEEN VARIOUS TYPES OF MUTUAL FUNDS}

The fund returns were collected for the period 20.10.2019-20.10.2020 and introduced in Excel. In the following analysis we will present a comparison between various type of mutual funds, depending on their annual performance and their risk level. 
BUGHEANU, A.M., DINULESCU, R., PUCHEANU, F..

EMPIRICAL STUDY ON ALTERNATIVES FOR SAVING AND INVESTING IN THE POST-PANDEMIC PERIOD.

CASE STUDY: ROMANIA

TABLE 1. MUTUAL FUNDS WITH LOW-MEDIUM RISK LEVEL. STOCK INVESTMENT PERCENTAGE: <35\% OF THE TOTAL FUND

\begin{tabular}{|c|c|c|c|}
\hline Fund name & $\begin{array}{l}\text { Last 12-month return } \\
\qquad(\%)\end{array}$ & $\begin{array}{l}\text { Percentage of stocks } \\
\text { * if specified in the fund } \\
\text { prospectus }\end{array}$ & Risk level \\
\hline BRD Diverso Clasa A & $-2,72$ & 11,72 & 4 \\
\hline BRD Simplu & 0,00 & 0,00 & 1 \\
\hline Raiffeisen Benefit & 0,20 & 0,00 & 3 \\
\hline BT Clasic & 1,06 & 26,26 & 3 \\
\hline ERSTE Bond Flexible RON & 1,64 & 0,00 & 2 \\
\hline Fortuna Gold & 1,67 & 11,34 & 3 \\
\hline Patria Obligatiuni & 1,69 & 0,00 & 1 \\
\hline Raiffeisen Ron Plus (D) & 1,77 & 0,00 & 2 \\
\hline Raiffeisen Confort & 1,89 & 7,19 & 3 \\
\hline Raiffeisen Ron Flexi & 2,16 & 0,00 & 1 \\
\hline $\begin{array}{l}\text { Erste Liquidity RON (fost Erste } \\
\text { Money Market RON) }\end{array}$ & 2,29 & 0,00 & 2 \\
\hline OTP Obligatiuni Clasa R & 2,59 & 0,00 & 2 \\
\hline OTP ComodisRO & 2,70 & 0,00 & 1 \\
\hline BT Obligatiuni & 2,85 & 0,00 & 1 \\
\hline BT FIX & 2,96 & 0,00 & 1 \\
\hline Raiffeisen Ron Plus (A) & 3,07 & 0,00 & 2 \\
\hline FDI FIX INVEST & 3,09 & 4,63 & 2 \\
\hline BRD Simfonia 1 & 3,25 & 0,00 & 2 \\
\hline OTP Obligatiuni Clasa I & 3,36 & 0,00 & 2 \\
\hline BRD Obligatiuni & 3,81 & 0,00 & 2 \\
\hline Certinvest Obligatiuni & 4,06 & 0,00 & 1 \\
\hline $\begin{array}{l}\text { NN (L) International Romanian } \\
\text { Bond }\end{array}$ & 4,72 & 0,00 & 3 \\
\hline
\end{tabular}

Source: Authors' computations

The graphic representation is presented in Figure 2. 
BUGHEANU, A.M., DINULESCU, R., PUCHEANU, F.. EMPIRICAL STUDY ON ALTERNATIVES FOR SAVING AND INVESTING IN THE POST-PANDEMIC PERIOD. CASE STUDY: ROMANIA

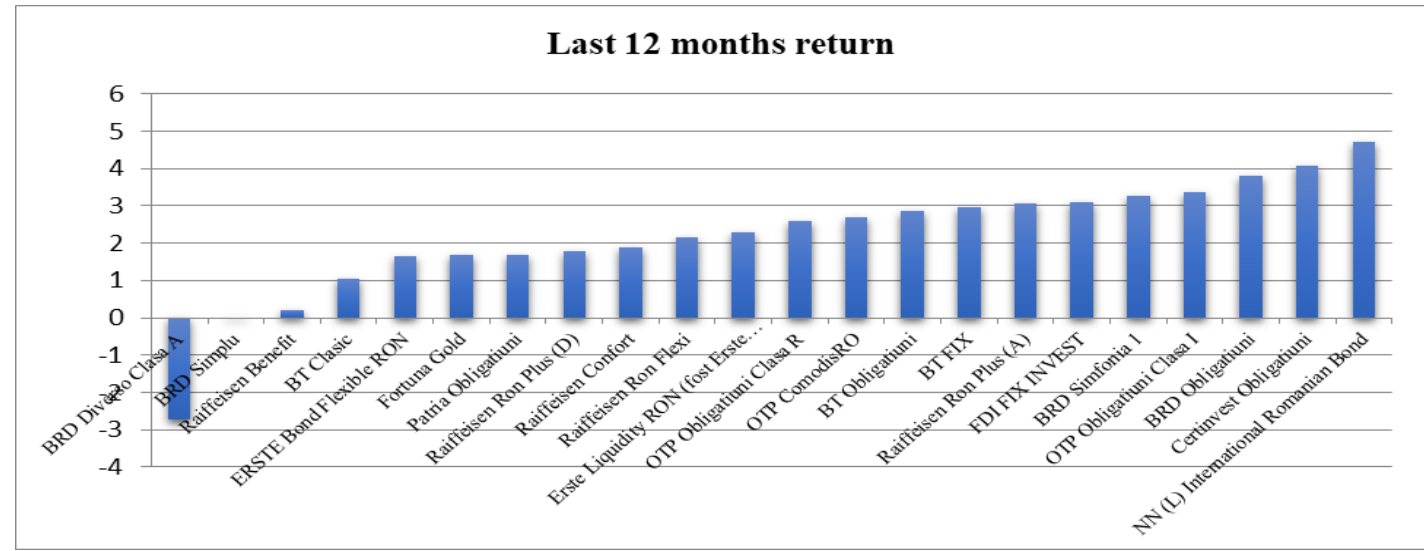

FIGURE 2. LAST 12 MONTH RETURN FOR FUNDS WITH LOW RISK LEVEL

Source: Authors' representation

TABLE 2: MUTUAL FUNDS WITH MEDIUM-HIGH RISK LEVEL. STOCK INVESTMENT PERCENTAGE: $35-70 \%$ OF THE TOTAL FUND

\begin{tabular}{|c|c|c|c|}
\hline Fund name & $\begin{array}{l}\text { Last 12-month return } \\
\qquad(\%)\end{array}$ & $\begin{array}{c}\text { Percentage of stocks } \\
\text { * if specified in the fund } \\
\text { prospectus }\end{array}$ & Risk level \\
\hline Omninvest & $-10,71$ & 43,88 & 4 \\
\hline Certinvest Dinamic & $-7,24$ & 44,62 & 4 \\
\hline Patria Stock & $-6,89$ & 48,06 & 4 \\
\hline Transilvania & $-6,84$ & 39,79 & 4 \\
\hline $\begin{array}{l}\text { OTP Real Estate \& } \\
\text { Construction - Clasa L }\end{array}$ & $-6,78$ & 46,89 & 4 \\
\hline Amundi Integro & $-4,40$ & 46,62 & 4 \\
\hline Fortuna Clasic & $-3,72$ & 67,29 & 4 \\
\hline ERSTE Balanced RON & $-2,72$ & 48,26 & 4 \\
\hline FDI PLUS INVEST & $-0,83$ & 53,52 & 5 \\
\hline FDI Prosper Invest & 1,46 & 64,11 & 4 \\
\hline Piscator Equity Plus & 2,79 & 65,34 & 4 \\
\hline $\begin{array}{l}\text { OTP Premium Return - } \\
\text { Clasa L }\end{array}$ & 5,63 & 41,34 & 4 \\
\hline
\end{tabular}

Source: Authors' computations

The graphic representation is presented in Figure 3. 
BUGHEANU, A.M., DINULESCU, R., PUCHEANU, F..

EMPIRICAL STUDY ON ALTERNATIVES FOR SAVING AND INVESTING IN THE POST-PANDEMIC PERIOD.

CASE STUDY: ROMANIA

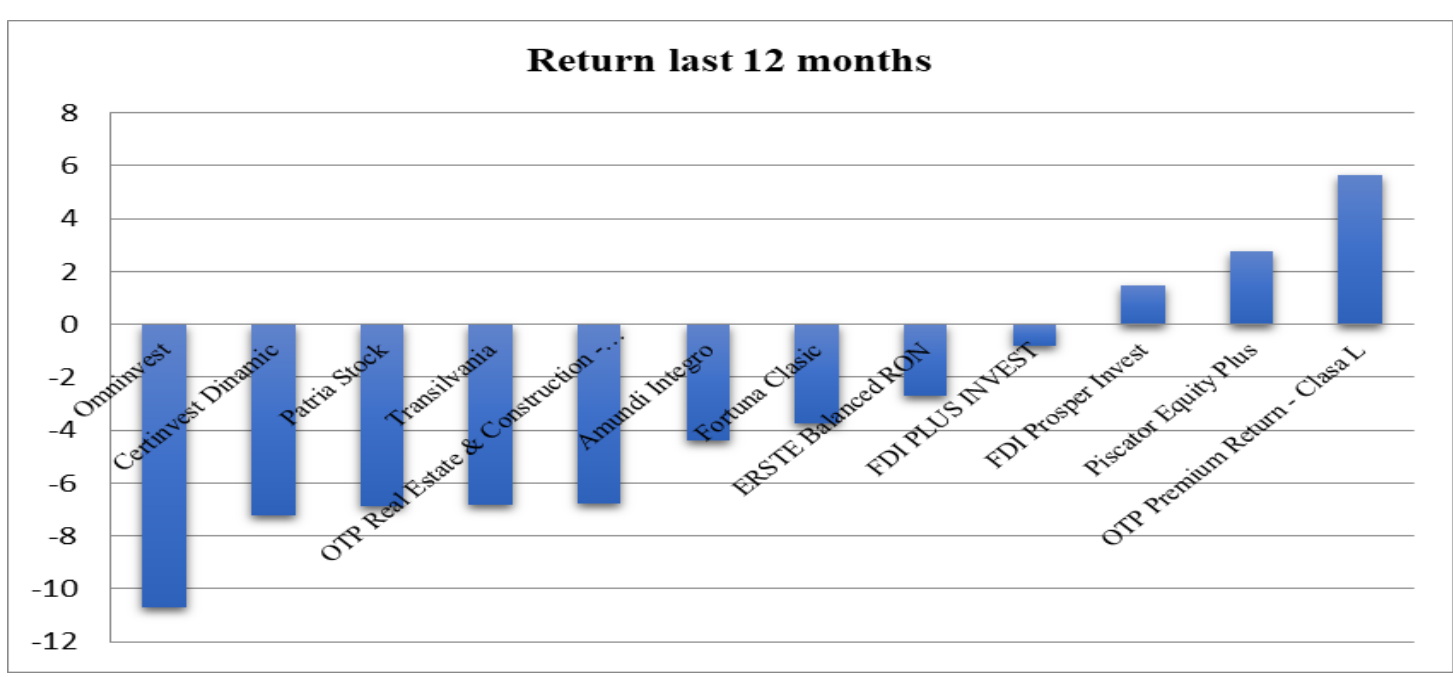

FIGURE 3. LAST 12 MONTH RETURN FOR FUNDS WITH MEDIUM-HIGH RISK LEVEL

Source: Authors' analysis based on own data

\section{THE CONCEPT OF FINANCIAL INDEPENDENCE}

Taking all the information into consideration, it is imperative to also evaluate the potential advantages of saving in investing. Therefore, it is mandatory to present and analyze the concept of Financial Independence: meaning, implications, desirability and also benefits. Additionally, we will briefly assess the FIRE movement.

First of all, we need to present the concept of Financial independence (F.I.).

Generally, F.I. stands for the financial status of any individual that managed to accumulate an amount of money large enough to sustain his current cost of living for the rest of his life without having to be employed or dependent on others. In other words, any person that does not have to work for the rest of your life.

Although this may be true, the concept is not that straightforward and effortless. Point often overlooked, one obvious condition is that the individual needs to maintain the level of their current expenses. In other words, the quality of life must remain unchanged.

With this in mind, we should always remember that "Retirement isn't an age-it's a financial number" (Hogan, 2019). As a result, from this theory of financial independence, the FIRE movement emerged.

Specifically, the concept of F.I.R.E. or the movement F.I.R.E. stands for "Financial Independence, Retire Early." For this reason, the main objective here is to save and invest very aggressively - somewhere around $50-75 \%$ of the monthly income, to retire as fast as possible.

To put it differently, is all about achieving financial independence at a young age, rather than waiting until the year of approximately 65 years old to retire. In the long run, F.I.R.E. movement adepts are interested in 
BUGHEANU, A.M., DINULESCU, R., PUCHEANU, F..

creating enough wealth to allow them to maintain their desired standard of living after retiring in their $30 \mathrm{~s}$, 40 s or 50 s.

In a word: every individual needs to save and invest at least half of their income, moreover since various unwanted events, like the COVID-19 pandemic, can appear.

What is crucial to understand is the fact that people who are trying to achieve F.I.R.E. are always looking to do two things: keep their expenses extremely low and increase their income.

In conclusion, the general idea is that the higher the income is and the lower the expenses are, a person is more likely to achieve their financial goals sooner.

As an example, a simple analysis to assess the number of years one does need to achieve F.I.R.E is presented in Table 3.

\section{TABLE 3: YEARS NEEDED TO ACHIEVE FINANCIAL INDEPENDENCE DEPENDING ON THE AVERAGE RATE OF SAVING AND INVESTING}

\begin{tabular}{|c|c|}
\hline Average rate or saving and investing & $\begin{array}{l}\text { Number of years until Financial } \\
\text { Independence/Retirement }\end{array}$ \\
\hline $80 \%$ & 5 years \\
\hline $65 \%$ & 10 years \\
\hline $50 \%$ & 15 years \\
\hline $35 \%$ & 20 years \\
\hline
\end{tabular}

Source: Authors' own analysis

In summary, an individual is required to save and invest the previous percentages from their annual income. The analysis is valid if we take into consideration an average annual return of $8-10 \%$ and the effect of compounding interest.

All things considered, the top benefits of achieving Financial Independence could be resumed as:

1. One can live their life on its own terms.

This is one of the greatest advantages. The person will decide how much time they want to work, when, and for whom. Of course, taking into consideration the fact that you will still participate in some projects from time to time.

\section{Substantial financial security}

If an individual does not depend on a specific salary, then they will have the freedom the make more fearless decisions, not only at their job, but in their entire life.

3. The possibility of early retirement 
BUGHEANU, A.M., DINULESCU, R., PUCHEANU, F..

EMPIRICAL STUDY ON ALTERNATIVES FOR SAVING AND INVESTING IN THE POST-PANDEMIC PERIOD.

CASE STUDY: ROMANIA

There are several advantages when analyzing early retirement. For instance, we can include here health benefits, new opportunities to travel and spending time with the family, starting a completely new career or business venture.

\section{Better management of stress and anxiety}

Point often overlooked, money is in a direct correlation with financial stress, and it can make an individual feel vulnerable and anxious. With this in mind, if a person removes them from the equation, things will start to look better on long-term.

For the majority of stock markets, March $20^{\text {th }} 2020$ was one of the decisive turning points. It needed almost five months to reiterate the initial Covid-19 losses and begin achieving new all-time highs. According to specialists, the pandemic year 2020 should have taught us seven investing lessons for achieving the Financial Independence state, like:

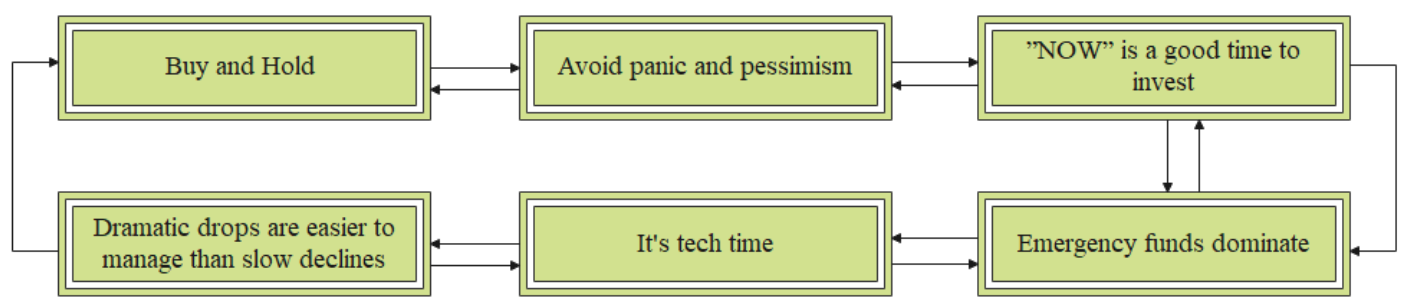

FIGURE 4. INVESTING LESSONS

Source: The Authors

Even if the pandemic is almost over, the actual stock movements of this year still remind us of the uncertainty of the market crash. The investors struggle to recover their funds, however the covid-19 pandemic still left traces over the investment portfolios and some markets and financial instruments still vary in stability since they have been affected at a certain level.

\section{METHODOLOGY AND RESEARCH RESULTS}

Since the Romanian investors were affected, more or less, by the COVID-19 pandemic regarding their investment decisions, we have decided to create a simple survey to find out their opinions related to the impact of the pandemic on their investment decisions. Thus, we created an online survey with 4 questions, and received the answers of 112 respondents (the survey was meant only for those who had active investment portfolios before the beginning of the pandemic, thus were already the followers of the Financial Independence).

Their answers are summarized as follows:

$\checkmark$ Q1: What is your current trading status (for the year 2021)? 
BUGHEANU, A.M., DINULESCU, R., PUCHEANU, F..

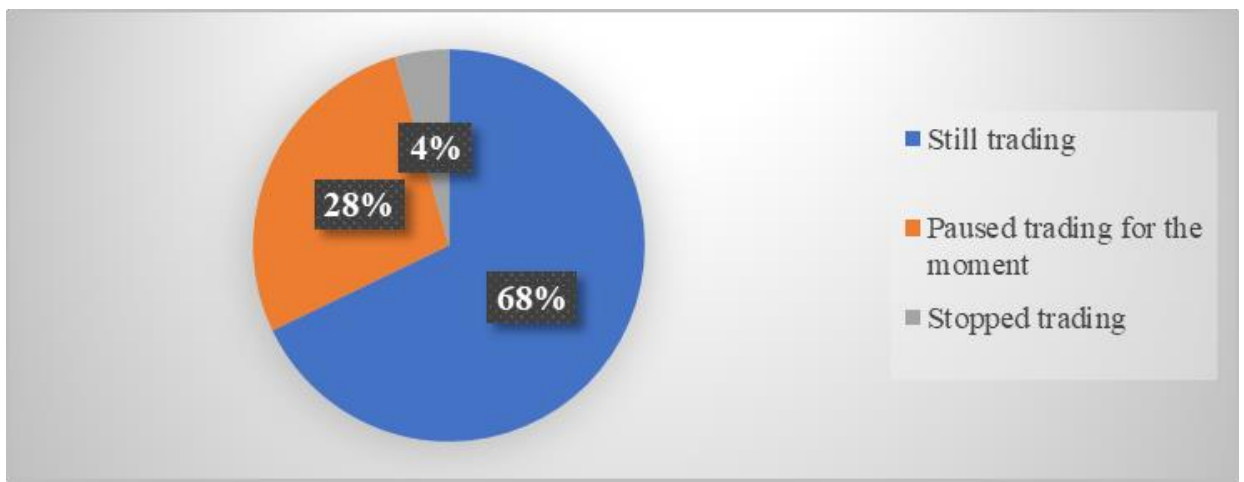

FIGURE 5. CURRENT TRADING STATUS

Source: The Authors

Even if for some of us, the Covid-19 pandemic from 2020 was not the best year for investing, and for others was one of the most opportunistic moment, still most of our respondents, $68 \%$, continued to trade, without losing hope (some of them even doubled their profits), while $28 \%$ of our respondents paused the trading due to various expenses which have been covered from the investment profits. Only $4 \%$ of the respondents stopped the trading mentioning that the pandemic year represents a risky period for investments, and that the market presents a high degree of volatility.

Q2: After the COVID-19 pandemic, what are your plans related to assets for the next 6 months?

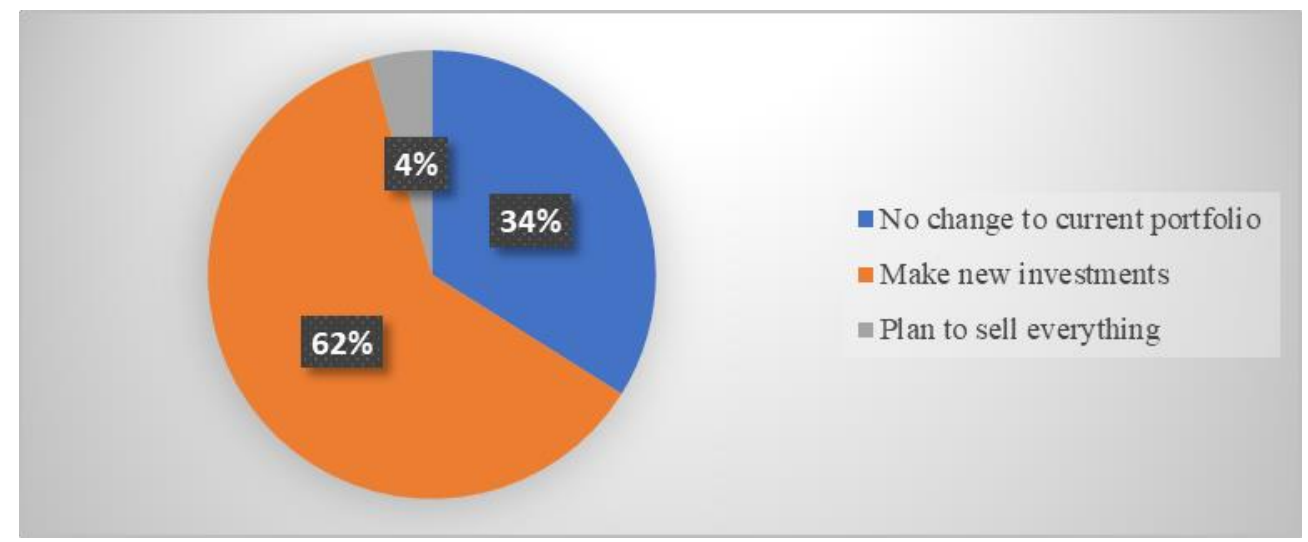

FIGURE 6. PLANS RELATED TO ASSETS

Source: The Authors

Regarding the eventual investment plans after the pandemic is over, $62 \%$ of our respondents keep their optimism at a high level and take new chances with new investments. $34 \%$ of the respondents are more 
BUGHEANU, A.M., DINULESCU, R., PUCHEANU, F..

EMPIRICAL STUDY ON ALTERNATIVES FOR SAVING AND INVESTING IN THE POST-PANDEMIC PERIOD.

CASE STUDY: ROMANIA

cautious and prefer to avoid changes in their current portfolio, while $4 \%$ plan to sell their investment funds and take out the profit.

$\checkmark$ Q3: How do you expect investments fees (like trading fees, broker fees, expense ratio, etc) to change over the next 12 months?

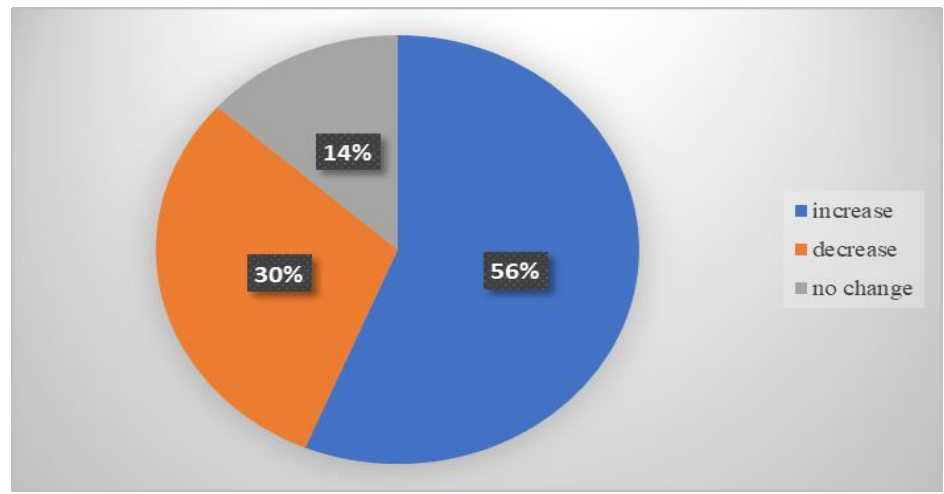

FIGURE 7. INVESTMENT FEES

Source: The Authors

Based on the above figure, most of our respondents consider that the investments cost will increase in 2021, with a sequel in 2022 as well.

While 2020 was a year that put a pause on investors' thoughts, many of them decided to sell their assets (investments) because of the pandemic. For this reason and because some of the investors have abandoned the ship, investment fees might have an ascending trend in 2022 as well.

From the respondents' answers, only $30 \%$ of them consider that the fees will decrease, while $14 \%$ consider that there will not be any change regarding the investment fees.

$\checkmark$ Q4: Do you think 2021 will be a bullish or bearish year? 


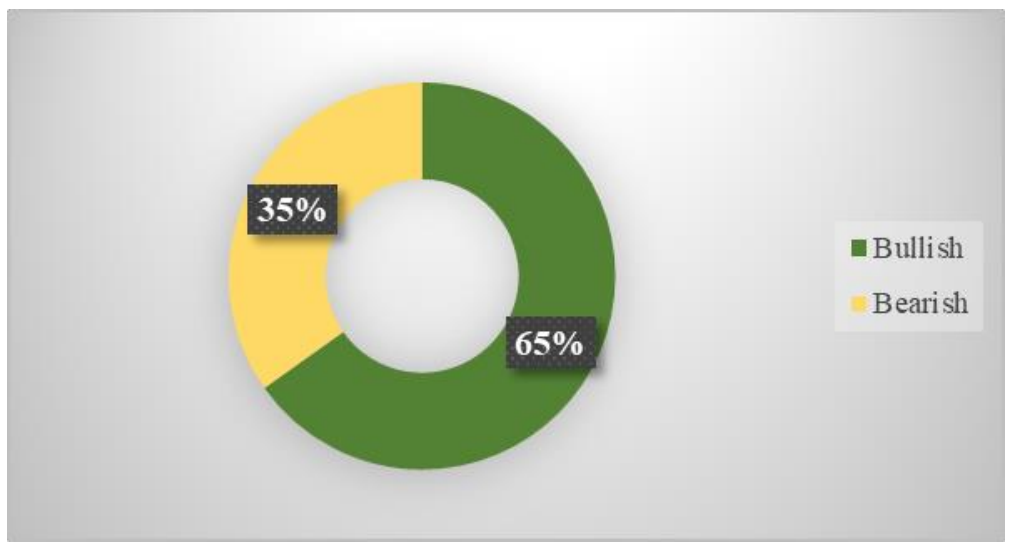

FIGURE 8. BEARISH OR BULLISH

Source: The Authors

In conclusion, more than a half of the respondents, respectively 65\%, consider 2021 as being a year full of opportunities regarding the investment stock market, even if the pandemic seriously affected a part of the industries. Thus, the investors consider that the year 2021 will have bullish trends (the stocks will increase) especially since the economic sector will reborn after the major lockdown.

\section{CONCLUSIONS}

The COVID-19 pandemic has a serious impact on the socio-economic situation of Romania. It is a turning point in the activities of many sectors, as well as for the directions of development of the entire economies.

There is a saying suggesting that the stock market is seen as a "barometer" of an entire economy - true fact when we talk about economies with developed capital markets that had to face a worldwide pandemic. Integrating financial markets into the world capital market and encouraging them to develop after the COVID-19 pandemic becomes an advantage for the economic growth, especially for the eastern European countries, given the fact that the number of investments is rapidly increased due to the access to foreign capital.

Furthermore, integrating the financial market is also mandatory for obtaining an efficient monetary policy which could enlarge the monetary vision, especially when various degrees of financial market integration might create different reactions on monetary shocks.

Regarding from a macroeconomic perspective, a country can reach its economic growth by having the possibility to ensure the access of many investors on financial markets, under the belief that performer economic individuals will receive financial benefits. Also, from an academic perspective, analysing the evolution of the resources presented on the stock market, with reference to investors' behaviours might illustrate a significant matter. 
BUGHEANU, A.M., DINULESCU, R., PUCHEANU, F.. EMPIRICAL STUDY ON ALTERNATIVES FOR SAVING AND INVESTING IN THE POST-PANDEMIC PERIOD. CASE STUDY: ROMANIA

Furthermore, even if the Romanian trading market, in comparison to other European countries, is still at the beginning, regarding the shared knowledges, more and more people are attracted to short- and longterm investments. People are not satisfied to live, day by day, based only on their salaries; they feel the need to invest their financial resources in various assets which, in the future, will result in financial benefits. For Romania, a country which passed through a communist era, it is difficult to embrace the new perspectives that other countries have already adopted. However, if the investment and trading market will become part of the national educational curriculum, it will definitely captivate a large number of people, who will become interested in the concepts.

\section{REFERENCES}

Bahmani-Oskooee, M., Chang, T., Wu, T. 2014. Revisiting purchasing power parity in African countries: panel stationary test with sharp and smooth breaks. Applied Financial Economics,24(22):1429-1438. https://www.tandfonline.com/doi/abs/10.1080/09603107.2014.925068

Bai, Y., Zhang, J. 2010. Solving the Feldstein-Horioka puzzle with financial frictions. Econometrica, 78(1): 603-632.

Baxter, M. Crucini, M.J. 1993. Explaining saving-investment correlations. American Economic Review, 83(3): 416-436.

Caporale, G. M., Howells, P., and Soliman, A. M. 2004. Stock Market Development And Economic Growth: The Causal Linkage. Journal Of Economic Development, 29(1), 33-50. https://ideas.repec.org/a/jed/journl/v29y2004i1p33-50.html

Chang, Y., Smith, R. 2014. Feldstein-Horioka puzzles. European Economic Review, 72(C): 98-112.

Chu, K. 2012. The Feldstein-Horioka puzzle and spurious ratio correlation. Journal of International Money and Finance, 31(2): 292-309.

Coakley. J, Kulasi. F, Smith, R. 1996. Current account solvency and the Feldstein-Horioka puzzle. Economic Journal, 106(1): 620-627.

Collins, S. Dani, R. 1991. Eastern Europe and the Soviet Union in the World Economy. Journal of International Economics, 32(3-4): 389-392.

Dooley, M.P., Frankel, J., Mathieson, D.J. 1987. International capital mobility- what do savinginvestment correlations tell us? IMF staff papers. International Monetary Fund, Washington, DC, 34: 503-530

Eiriksson, A.A. 2011. The saving-investment correlation and origins of productivity shocks. Japan and the World Economy, 23(1): 40-47.

Glick, R., Rogoff, K. 1995. Global versus country-specific productivity shocks and the current account. Journal of Monetary Economics, 35(1): 159-192.

Harberger, A. 1980. Vignettes on the world capital market. American Economic Review, 70(2): 331337.

Harris, M., Loundes, J.and Webster, E. 2002. Determinants of household savings in Australia, Economic Record, 78(241): 207-223 
BUGHEANU, A.M., DINULESCU, R., PUCHEANU, F..

Hogan, Chris. 2019. Ramsey Solutions. https://www.daveramsey.com/. [Online] Ramsey Solutions, 10 29, 2019. [Cited: 12 30, 2020.] https://www.daveramsey.com/blog/retirement-is-not-an-age-itsa-financial-number.

Levy, D. 1995. Investment-saving co-movement under endogenous fiscal policy. Open Economic Review, 6(3):237-254.

Murphy, R. 1984. Capital mobility and the relationship between saving and investment rates in OECD countries. Journal of International Money and Finance, 3(1): 327-342.

Obstfeld, M., Rogoff, K. 2000. The Six Major Puzzles in International Macroeconomics: Is There a Common Cause? NBER Working Paper, W7777, Cambridge

Rasin, A. 1993. The dynamic-optimizing approach to the current account: Theory and evidence. NBER Working Paper, W4334. National Bureau of Economic Research, Cambridge

Watchel, P. 2003. How Much Do We Really Know about Growth and Finance?. Federal Reserve Bank of Atlanta Economic Review, 88(1): 33-47. https://ideas.repec.org/a/fip/fedaer/y2003iq1p33$\underline{47 n v .88 n o .1 . h t m l}$ 